\title{
濕黑球寒暖計に関する補見 \\ Complemental Observation on the Wet Globe Thermometer
}

\author{
大阪大学医学部衞生学教室 (主任 梶原三郎教授) \\ 砂田毅 \\ Tsuyoshi Sunada \\ Department of Hygiene, Medical School, Osaka University \\ (Director: Prof. S. Kajiwara)
}

\section{序言}

高温環境におりる温度条件の総合表示法として梶原は 圂に湿黒球寒暖計を提案されていたが ${ }^{11}$ ，その物理的特 性に関する知見を欠いていた。今回の実験はこの欠点を 充たすととを目的としたものである。

\section{理論よりみた実験式}

\section{I. 滀球の理論}

湿球に関する理論としては August が初めて理論式を 作つたが，乙れには風速の影響が考慮されていなかつ た。その後, Grossmann, Regnault, Taylor, Birkland, Watson, Pertner, Edelmann, Davis ${ }^{2}$.等が風速 の影響を考えに入れて理論及び実験を進めた。

結局現在のところ, 次式が一般に承認されている。即 与,

$$
e=e_{m}-\frac{H C_{p}}{L \sigma}\left(\theta-\theta^{\prime}\right) f_{(v)} \cdots \cdots \cdots \cdots
$$

たたしし

$e:$ pressure of aqueous vapor in the air $(\mathrm{mm}$ $\mathrm{Hg}$ )

$e_{m}:$ maximum pressure of aqueous vapor at a temperature $\theta^{\prime}(\mathrm{mm} \mathrm{Hg})$

$\theta$ : air temperature $\left({ }^{\circ} \mathrm{C}\right)$

$\theta^{\prime}$ : temperature of the wet bulb $\left({ }^{\circ} \mathrm{C}\right)$

$H$ : whole pressure of the air $(\mathrm{mm} \mathrm{Hg}$ )

$L$ : latent heat of water at $\theta^{\prime}(\mathrm{cal} / \mathrm{gr})$

$\sigma$ : specific gravity of aqueous vapor compared with air

$C_{p}$ : specific heat of air at constant pressure $\left(\mathrm{cal} / \mathrm{gr}^{\circ} \mathrm{C}\right)$

$v$ : velocity of air stream $(\mathrm{ft} / \mathrm{min})$ |

とする。
いま我々が取扱つている湿黒球寒暖計は黒球寒暖計の 表面に水を含ませて置いたものである。相似の観点から して黒球寒暖計を乾球, 湿黒球寒暖計を湿球とみなし, 前者の示度を $\theta_{d g}$, 後者の示度を $\theta_{w g}$ とすると, (1) の $\theta, \theta^{\prime}$ にこれらを代入して,

$$
e=e_{m g}=\frac{H C_{p}}{L \sigma}\left(\theta_{d g}-\theta_{w g}\right) f_{(v)} \cdots \cdots
$$

アだし

$e_{m: g}:$ maximum pressure of aqueous vapor at a temperature of the wet globe thermometer $\theta_{w g}$ (2) 式を変形して

$$
\frac{\left(e_{m g}-e\right) L}{\left(\theta_{d g}-\theta_{w g}\right) H}=\frac{C_{p}}{\sigma} f_{(v)}
$$

さて $C_{p}, \sigma$ の值は我々の計器の使用範囲 からすれば 常数と考えてよい。 $L$ の值は正しくは

$$
L=606.5-0.695 \theta_{w g}
$$

であるが，通風乾湿球湿度計においては（1)式より

$$
\begin{gathered}
e=e_{m}-\left\{\frac{C_{p}}{\sigma} f_{(v)}\right\} H\left(\theta-\theta^{\prime}\right) \frac{1}{L} \text { と変形し } \\
L=610-\theta^{\prime} \text { として } L=610\left(1-\frac{\theta^{\prime}}{610}\right) \text { なる故 } \\
e=e_{m}-\left\{\frac{C_{p}}{\sigma} f_{(v)}\right\} H\left(\theta-\theta^{\prime}\right) \frac{1}{610\left(1-\frac{\theta^{\prime}}{610}\right)} \\
\text { そこで } \frac{C_{p}}{610 \sigma} f_{(v)} \equiv A \text { とおけば } \\
e=e_{m}-A H \quad\left(\theta-\theta^{\prime}\right)\left(1+\frac{\theta^{\prime}}{610}\right)
\end{gathered}
$$

として $L$ を取扱つている。我々もこれにならつて $L$ の 値を $L=610-\theta w g$ とするととにすると（3)式梳

$$
\frac{\left(\boldsymbol{e}_{m g}-\boldsymbol{e}\right)\left(610-\theta_{i v g}\right)}{\left(\theta_{d g}-\theta_{w g}\right) H}=F_{(v)} \ldots \ldots
$$

となる。左辺の値は実験により間接測定されるから $v$ の 值を種々変えることにより（4)式の函数形は実験により 
定まる。

なお実験式は簡単なものがより望ましいから（4)式に おりる $L, H$ の値も常数と及なせば:

$$
\frac{e_{m g}-e}{\theta_{d g}-\theta_{w g}}=\Phi_{(v)}
$$

となるから，実験により（4）及び（5）式を決定して行 く。

\section{II. 予備実験（柦g の計り方）}

乾湿球湿度計より dimension が大きく，その上に， 高温環境で本計器を用いる機会が多いことから，普通の 乾湿球湿度計の如く球に布 (ガーゼ) を付して下の水盇 から毛細管現象を利用して, 蒸発により失つた水分を補 万方法では湿球が乾き上つてしまう虞がある。そこで湿 球の上から水を 滴下または流下させる方法を取りたい が，そうすると前節の式は適用しがたくなる。（流下の 方法に関する考察は後で述べる。なんとなれぼ一定風速 下に括いて，気温より $\theta_{w g}$ が低认場合と高い場合とを考 えてみるに，水を球に流下すると前者の場合は $\boldsymbol{\theta}_{w g}$ より 高い温度の水によつて球が暖められるため実際の $\boldsymbol{\theta}_{w g}$ よ りも高い值を示す。反対に後者の場合は水により冷却さ れて実際の $\theta_{w g}$ よりも低い値を示す。その結果，一定風 速下における（4）及び（5）式の左辺の值は両者の場合 で異なつた値を示すことが容易に予測される。

ての事実は次に示す実験結果によつて分明する。即ち いま黒球寒暖計にガーゼを一重に緾い，マリオット嚗か らこの表面に蒸溜水を滴下させ 毎分当りの:供水量を一

Table 1. Incoincidence of $Y$-values in the cases of higher and lower value of $\theta_{w g}$ than $\theta$

(Amount of supplying water is $16 \mathrm{cc} / \mathrm{min}$ )

\begin{tabular}{cc|c|c|c|c}
\hline \multicolumn{2}{c|}{$\begin{array}{c}\text { Amount of } \\
\text { supplying water } \\
\mathrm{V}(\mathrm{cc} / \mathrm{min})\end{array}$} & 16 & 16 & $0^{*}$ & $0^{*}$ \\
\hline$\theta$ & $\left({ }^{\circ} \mathrm{C}\right)$ & 26.0 & 25.5 & 25.1 & 25.1 \\
$\theta^{\prime}$ & $\left({ }^{\circ} \mathrm{C}\right)$ & 21.3 & 19.3 & 20.2 & 20.1 \\
$\theta_{\boldsymbol{d} g}$ & $\left({ }^{\circ} \mathrm{C}\right)$ & 54.0 & 30.5 & 37.0 & 35.3 \\
$\theta_{w g}$ & $\left({ }^{\circ} \mathrm{C}\right)$ & 31.2 & 22.5 & 25.6 & 24.9 \\
$e$ & $(\mathrm{mmHg})$ & 16.646 & 13.689 & 15.303 & 15.144 \\
$\boldsymbol{e}_{m g}$ & $(\mathrm{mmHg})$ & 34.082 & 20.440 & 24.617 & 23.616 \\
$H$ & $(\mathrm{mmHg})$ & 769 & 769 & 766 & 761 \\
$\boldsymbol{v}$ & $(\mathrm{m} / \mathrm{sec})$ & 0.2 & 0.2 & 0.2 & 0.2 \\
$Y=\frac{e_{m g}-e}{\boldsymbol{\theta}_{\boldsymbol{d g}}-\boldsymbol{\theta}_{w g}}\left(\mathrm{~mm} /{ }^{\circ} \mathrm{C}\right)$ & 0.765 & 0.844 & 0.817 & 0.815 \\
\hline
\end{tabular}

Note : * See explanation in the following sentence
定 $(16 \mathrm{ml} / \mathrm{min})$ にして, 気温より高い的的示す環境と， 気温より 低い $\theta_{w g}$ の值を示す環境に置いて前記 (5) 式 の左辺の值を求めてみた。結果を第 1 表に示す。

即ち一定風速下で $\left(e_{m g}-e\right) /\left(\theta_{d g}-\theta_{w g}\right)$ の值は両者の 場合一致していない。第 1 表の右 2 列は後述の方法で測 つたもので，よく一致しているのをみる。

次に湿黒球に供給する水量の多少によつて $\left(e_{m g}-e\right)$ l $\left(\theta_{d g}-\theta_{w g}\right)$ の值がいかに変るかを第 2 表に示す。

\section{Table 2. Variation of $\boldsymbol{Y}$-value with amount of supplying water}

$\left(\theta, \theta^{\prime}\right.$ and $\theta_{d g}$ are constant $)$

\begin{tabular}{|c|c|c|c|c|c|}
\hline \multicolumn{2}{|c|}{$\begin{array}{l}\text { Amount of } \\
\text { supplying water } \\
\mathrm{V}(\mathrm{cc} / \mathrm{min})\end{array}$} & \multirow[b]{2}{*}{17.8} & \multirow{2}{*}{\begin{tabular}{|r}
5 \\
17.8
\end{tabular}} & \multirow{2}{*}{$\frac{16}{17.8}$} & \multirow{2}{*}{\begin{tabular}{|c|}
67 \\
17.8
\end{tabular}} \\
\hline$\theta$ & $\left({ }^{\circ} \mathrm{C}\right)$ & & & & \\
\hline$\theta^{\prime}$ & $\left({ }^{\circ} \mathbf{C}\right)$ & 13.8 & 13.8 & 13.8 & 13.8 \\
\hline$\theta_{d g}$ & $\left({ }^{\circ} \mathrm{C}\right)$ & 18.0 & 18.0 & 18.0 & 18.0 \\
\hline$\theta_{i v g}$ & $\left({ }^{\circ} \mathrm{C}\right)$ & 15.1 & 15.9 & 16.2 & 16.5 \\
\hline$e$ & $(\mathrm{mmHg})$ & 9.833 & 9.833 & 9.833 & \begin{tabular}{l|l}
3 & 9.833
\end{tabular} \\
\hline$e_{m g}$ & $(\mathrm{mmHg})$ & 12.870 & 13.547 & 13.809 & 914.076 \\
\hline$H$ & $(\mathrm{mmHg})$ & 766 & 766 & 766 & 766 \\
\hline$v$ & $(\mathrm{~m} / \mathrm{sec})$ & 0.05 & 0.05 & 0.05 & 0.05 \\
\hline$\frac{e_{m}}{\theta_{d g}}$ & $\frac{-e}{\theta_{w g}}\left(\mathrm{~mm} /{ }^{\circ} \mathrm{C}\right)$ & 1.05 & 1.77 & 2.21 & 2.83 \\
\hline
\end{tabular}

上記第 $1 ， 2$ 表で落下水量 0 とあるのは，水を滴下し ないで，一度水で球を湿らしただけで放置したものであ る。第 2 表をみてわかるように $\theta_{w g}$ が気温より低い場合 には供給水量を多くする湮ど湿球は 水によつて暖めら れ，その示度が高くなつている。（供給水量がある限度 を越えると遂に $\theta_{w g}$ は水温, 即与気温と一致するととが 予測される。）換言すれば $V=0$ の時は湿つているが， $V か ゙$ 有限の時は濡れているわけである。我々がいま採用 している前節の式では $V=0$ の時の $\theta_{w g}$ の值を求めな ければならない。即ち「湿」黒球寒暖計であつて「濡」 黒球寒暖計ではない所以である。

そこで実際問題として正しい $\theta_{w g}$ の值を求める方法が 問題となる。気温 $\theta$ よりも $\theta_{w g}$ が低い場合には球を濡 らして後, 放置すれば $\theta_{w v g}$ の值は徐从に降下し, 下り切 つたととろで平衡状態に達するからその下り切つた時の 值を読めばよい。ところが他方 $\boldsymbol{\theta}_{\boldsymbol{v}}$ が気温 $\boldsymbol{\theta}$ より高い值 を示す場合には一度水を供給しても乾き上つてしまえば $\theta_{v g}$ は上昇してしまうし, 濡らせば下り過ぎるから,示度 を㜔取るに困難を感ずることが予測される。だから平衡 状態の下に示す真の $\boldsymbol{\theta}_{\boldsymbol{w}}$ の值が讜みうるかという疑問は 
Fig. 1. $\theta_{w g}$ to the state of equilibrium in the case of $\theta_{w g}$ higher than $\theta$

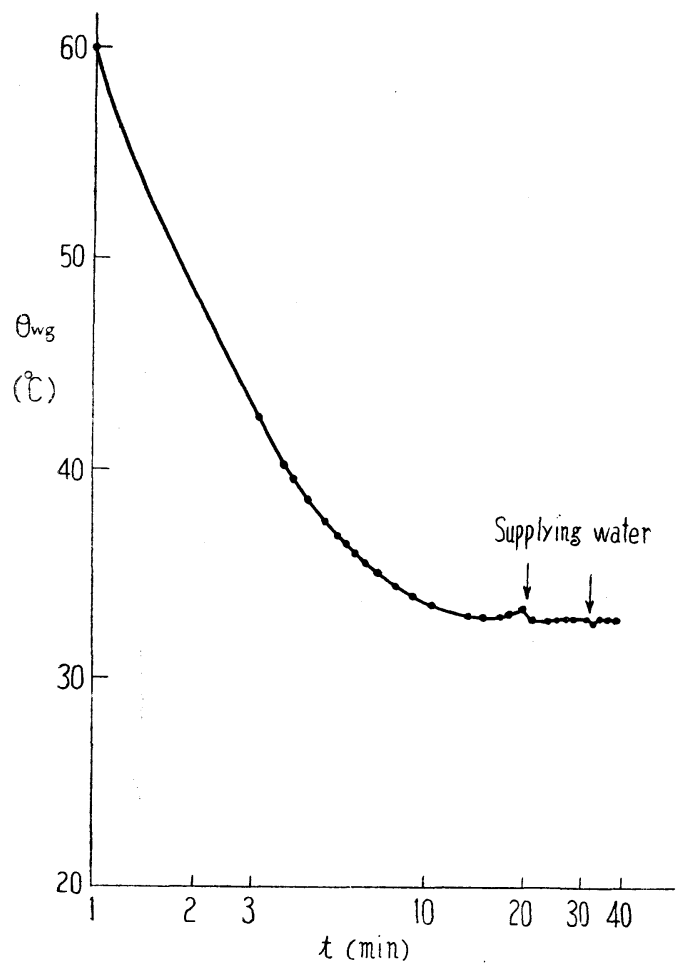

Note : $\theta_{w g}=32.9^{\circ} \mathrm{C}, \theta_{d g}=63.8^{\circ} \mathrm{C}, \theta=22.0^{\circ} \mathrm{C}$ $\theta^{\prime}=17.5^{\circ} \mathrm{C}, v=0.30 \mathrm{~m} / \mathrm{sec}, H=769 \mathrm{mmHg}$

Fig. 2. $\theta_{w g}$ to the state of equilibrium in the case of $\theta_{w g}$ lower than $\theta$

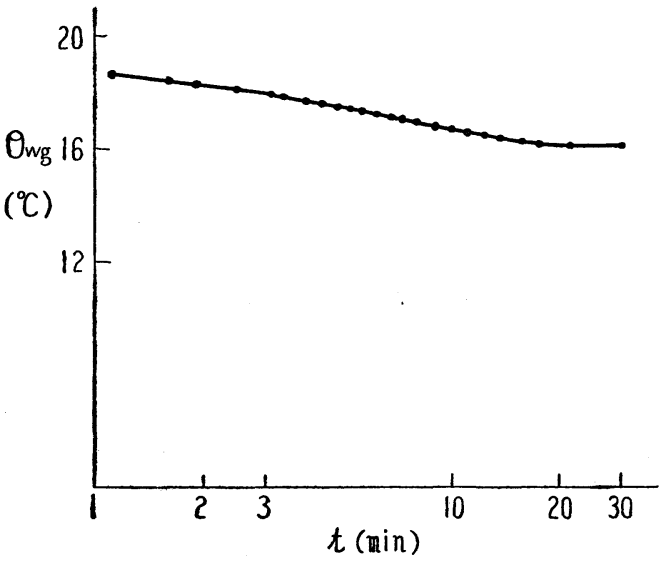

Note : $\theta_{w g}=16.1^{\circ} \mathrm{C}, \theta_{d g}=20.0^{\circ} \mathrm{C}, \theta=19.4^{\circ} \mathrm{C}$ $\theta^{\prime}=14.3^{\circ} \mathrm{C}, v=0.05 \mathrm{~m} / \mathrm{sec}, H=766 \mathrm{mmHg}$
当然起る。そこで次にその平衡状態に達する過程を時間 を追つてみてみよう。結果を第1図に示す。図でみられ る如く実効輻射温度の高い場合は初めの一回の供水だけ では平衡状態に達する前に乾く虞があるから示度の下降 が止み再び上昇して来た時更に水を噴霧器で供給する必 要があることがわかる。一度平衡状態に達すると，水を 供給すれば一旦示度は下るが再び乾かないのに平衡示度 に戻ることも図より判明する。この図の条件では最初に 平衡示度に到達するに 25 分定要し，確認に 35 分を要して いる。

平衡時間に関連して実効輻射温度の低い一例も参考の ため第 2 図に挙げて拉く。この実験の環境条件下で最初 に平衡示度に達するに約 20 分要し, 確認には 25 分を要し ている。

以上のととを要約して結局 $\theta_{w g}$ の值の取り方としては 気温より低い場合は水を布に万遍なく与えて後, 降下し て行くその最低值を取ればょい。また気温より高い場合 には水在布にふくませて後，降下して行く状態を検し， 湿りが手に触れて乾いたと感じられる際には, 更に噴霧 器で水を与えて持続状態に達した時の值を取ればよい。 その平衡状態に達する時間は約 $25 〜 30$ 分前後である。

\section{III. 実験方法}

径 $55 \mathrm{~cm}$ 角, 長さ $4 \mathrm{~m}$ の風洞を使用し, その中に黒球と 湿黒球を並列に吊下する。風は送風機により起す。風速 はヤグロー式加熱寒暖計風速計とカタ寒暖計を使用して 測定。な打気温及び水蒸気圧はアスマン式乾湿球湿度計 を時析湿黒球の直前に吊下して測定した。

実効輻射温度の高、領域は実験上の便宜と実用性を兼 ねて高輻射体 (Heater) と送風機学併置しその方向性を 考えて十字交錯する位置に球を設置して実験した。この 場合の風速は専ら加熱寒暖計風速計により測定。なお水 蒸気圧を変えるために水蒸気発生装置を使用した。

水蒸気圧測定にはアスマン式乾湿球湿度計を使用し， その算出には次式によつた ${ }^{3) \text { 4)。 }}$

$$
e=e_{m}-0.000656 H\left(\theta-\theta^{\prime}\right) \quad\left(1+\frac{\theta^{\prime}}{610}\right)
$$

な打簡便式 (5) の $e$ の算出には簡易性を考えて次式 によつた。

$$
e=e_{m}-0.5\left(\theta-\theta^{\prime}\right)
$$

気圧はフォルタン気压計を用いて測定し，その読みの 補正としては温度補正のみを行つた。

\section{IV. 実験結果}

結果を対数尺で図示すると第 3 図の如くなる。記載の 便宜上事後 
Fig. 3. Variation of $y$ and $Y$ with velocity of air stream in logarithmic scale

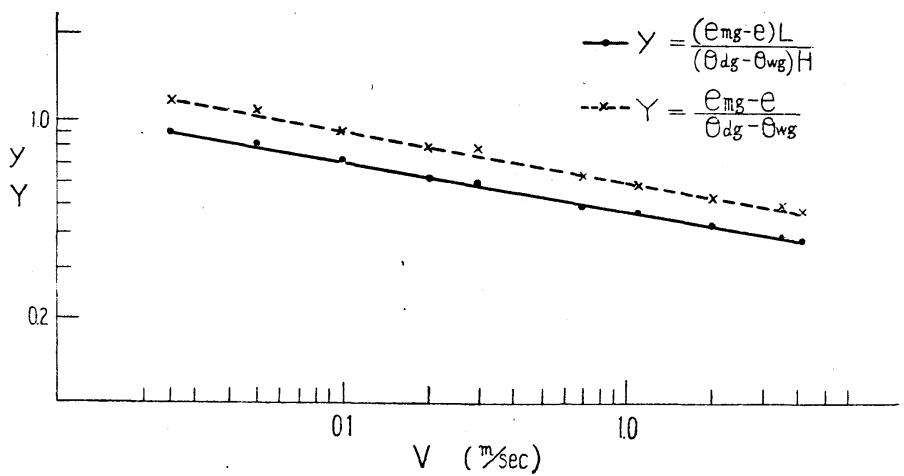

$$
\frac{\left(e_{m g}-e\right) L}{\left(\theta_{d g}-\theta_{w g}\right) H} \text { 岁, } y, \frac{e_{m g}-e}{\theta_{d g}-\theta_{w g}} \circlearrowright Y \text { と記す。 }
$$

\section{V. 実験式作製}

第 3 図の曲線からして $y, Y=a v^{\beta}+\gamma$ なる形が予測さ れる。最小二乗法により dataを処理して,

$$
\begin{aligned}
& y=0.035+0.446 v^{-0.185} \\
& L, H \text { を常数とみなした式は } \\
& Y=-0.037+0.653 v^{-0.171}
\end{aligned}
$$

しかるに Bedford によれば5

$$
\theta_{s}=\theta_{d g}+0.169 \sqrt{v}\left(\theta_{d g}-\theta\right)
$$

ただし

$\theta_{s}$ : mean surrounding temperature $\left({ }^{\circ} \mathrm{F}\right)$

$\theta:$ air temperature $\left({ }^{\circ} \mathrm{F}\right)$

$\theta_{d g}:$ temperature of the dry globe thermometer $\left({ }^{\circ} \mathrm{F}\right)$

$v$ : velocity of air stream $(\mathrm{ft} / \mathrm{min})$

従つて $\theta_{d g}=\frac{\theta_{s}+0.169 v^{0.5} \cdot \theta}{1+0.169 v^{0.5}}$

温度単位を ${ }^{\circ} \mathrm{C}$, 速さの単位定 $\mathrm{m} / \mathrm{sec}$ に換算すると

$$
\theta_{d g}=\frac{\theta_{s}+2.37 v^{0.5} \cdot \theta}{1+2.37 v^{0.5}}
$$

との式を上記 (6)式に代入して変形すると

$$
\left.\theta_{w g}=\frac{\theta_{s}+2.37 v^{0.5} \cdot \theta}{1+2.37 v^{0.5}}-\frac{L\left(e_{m g}-e\right)}{H\left(0.035+0.446 v^{-0.185}\right)}\right)
$$

$L, H$ を常数とみなした方は

$$
\left.\cdot \theta_{w g}=\frac{\theta_{s}+2.37 v^{0.5} \cdot \theta}{1+2.37 v^{0.5}}+\frac{e_{m g}-e}{0.037-0.653 v^{-0.171}}\right\}
$$

ただし $e_{m g}$ は $\theta_{w g}$ と函数関係にあり, Magnus の実 験式によれば6),

$$
e_{m g}=4.53 \times 10^{\frac{7.45 \theta_{w g}}{235+\theta_{w g}}}
$$

即ち $e_{m g}$ を parameter として上記 (7) 及び (8) 式 が湿黒球寒暖計の理論よりみた実験式となる。式中の変 数加明らかなように $\theta_{w g}$ は気温 $(\theta)$, 気流 $(v)$, 大気 水蒸気圧 $(e)$, 周囲輻射温度 $\left(\theta_{s}\right)$, 気圧 $(H)$ の函数で ある。

\section{港黑球寒暖計の各変数に対する態度}

各変数に対する態度をみるために（8）式を（7）式に 代入して $\theta_{w g}$ に関する陰函数の各変数に対する偏微分を 行つてみて行く。

\section{I. 気温との関係}

$\theta_{w g} \leqq 100^{\circ} \mathrm{C}$ とすると $\frac{\partial \theta_{w g}}{\partial \theta}$ は常に正となる。即ち $\theta_{w g}$ は気温の高低に従つて上昇下降を示す。

\section{II. 周囲輻射温度との関係}

$\frac{\partial \theta_{w g}}{\partial \theta_{s}}$ 治常に正となる。即与 $\theta_{w g}$ は周囲輻射温度の高 低につれ高低する。

III. 気压との関係
A. $e_{m g}-e>0$ の時

$\frac{\partial \theta_{w g}}{\partial H}>0$ 即与大気が水蒸気で飽和されていない時は $\theta_{w g}$ は気圧の高低従つて高低する。
B. $\boldsymbol{e}_{m: g}-\boldsymbol{e}=0$ の時

$\frac{\partial \theta_{w g}}{\partial H}=0$ 即与大気が水蒸気で飽和せる時は, $\theta_{w g}$ は気 圧の変化に関係しない。

IV. 風速との関係
A. $\theta_{s}>\theta$ の時

$\frac{\partial \theta_{v g}}{\partial v}<0$ 即与周柬輻射温度が気温より高い場合は $\theta_{w g}$ は風速の增加につれ低下する。 
B. $\theta_{s}=\theta$ の時

1) $e_{m g}-e>0$ の時: $\frac{\partial \theta_{w g}}{\partial v}<0$ 即与大気が水蒸気不 飽和で, かつ気温と周囲輻射温度が相等しい場合は $\theta_{w g}$ は風速の増加につれ低下する。

2) $e_{m g}-e=0$ の時: $\frac{\partial \theta_{w g}}{\partial v}=0$ 即与大気が水蒸気飽 和し, かつ気温が周囲輻射温度と相等しい場合は $\theta_{w g}$ は 風速に無関係である。

\section{C. $\theta_{\boldsymbol{s}}<\boldsymbol{\theta}$ の时}

1) $e_{m g}-\mathrm{e}>0$ の時: $\frac{\partial \theta_{w g}>0}{\partial v<0}$ 即与気温が周囲輻射 温度より高く, かつ大気が水蒸気不飽和の際は $\theta_{w g}$ は風 速の変化と一義的な関係がなく他の項によりそれぞれ異 なつた態度を示す。

2) $e_{m g}-e=0$ の時: $\frac{\partial \theta_{w g}}{\partial v}>0$ 即与気温が周囲輻射 温度より高く, かつ大気が水蒸気飽和の際は $\theta_{w g}$ は風速 の増加につれ上昇する。

\section{D. 黑球との比較}

との $\theta_{w g}$ と風速との関係を黒球寒暖計の態度と比較し てみよう。黒球は,

$$
\begin{aligned}
& \theta_{d g}=\frac{\theta_{s}+0.169 v^{0.5 \cdot \theta}}{1+0.169 v^{0.5}} \text { なる故 } \\
& \frac{\partial \theta_{d g}}{\partial v}=\frac{0.5 \times 0.169 v^{-0.5}\left(\theta-\theta_{s}\right)}{\left(1+0.169 v^{0.5}\right)^{2}} \text { となり }
\end{aligned}
$$

1) $\theta_{s}>\theta$ の時は $\frac{\partial \theta_{d g}}{\partial v}<0$ で, 淍囲輻射温度が気温よ り高い際は $\theta_{d g}$ は風速の増加につれ減少するから $\theta_{w g}$ の 態度と同様である。

2) $\theta_{s}=\theta$ の時は $\frac{\partial \theta d g}{\partial v}=0 て ゙$, 周囲輻射温度が気温と 等しい場合は $\theta_{d g}$ は風速の影響を受けない。これは wet globeの場合の湿度 $100 \%$ の時と同様である。 wet globe は湿度 $100 \%$ 未満の時は風速に影響を受けることは前述 の通りである。

3) $\theta_{s}<\theta$ の時は $\frac{\partial \theta_{d g}}{\partial v}>0$, 即与周囲輻射温度が気温 より低い場合は $\theta_{d g}$ は風速の増加につれ上昇する。乙れ は wet globe では湿度 100\%の時と同じ態度である。

即5 wet globe は気湿の factor が入つているため dry globe よりも複雑な態度を示すととがわかる。ただ 両者の態度の一致は湿度 $100 \%$ の時である。

\section{V. 大気水蒸気压との関係}

$\frac{\partial \theta_{w g}}{\partial e}>0$ なる故 $\theta_{w g}$ は大気水蒸気圧の高低に従つて
高低する。

\section{VI. 総 括}

今回の実験では風速の非常に大なる点での示度が得ら れなかつたが前記 (7)式から推測を許されるものとする と $v \rightarrow 0$ から $v \rightarrow \infty$ にわたつて 風速值が 小さいところ では $\theta_{\text {wog }}$ は輻射熱の影響を大いに受けているが，風速大 なるに従つて convection のため輻射熱の影響はもはや 無視できる程度になる。その中間の風速値の場合には気 温と輻射熱の種々の割合で前述の如く $\theta_{w g}$ は影響を受け ているととは dry globe と同様である。

かくてての湿黒球寒暖計は気温, 気湿, 風速, 輻射熱 （䈌密な意味でいえば更に気圧）の温熱因子の函数計器 であり，その熱収支の状態はこれら因子の我及生体に及 ぼす影響と基本的には矛盾のない態度を示すことが立証 された。

\section{温感賞と $\theta_{w g}$ の関保 (等温指数との相関)}

\section{I. 相関係数及び相関比}

T. Bedford は湿度 $100 \%$, 無風, 周囲が気温と同温 度である時を基にしてその時と等温感覚を与える状態を Equivalent Warmth と称した")。乙れは気温, 気湿, 気流及び輻射熱の 4 因子からなる一つの感覚的総合指数 である。との指数といまの湿黒球寒暖計示度とはその本 態からみれば明らかに完全な一致をみるものではない が，湿黒球寒暖計示度が我々の感覚的な温度とある程度 一致しなければその実用意義は失われる。4つの温度条 件からなる感覚的温度と湿黒球寒暖計温度との相関はこ の意味で見落してはならない問題である。

Bedford によれば”

Equivalent Warmth (E. W.)

$$
\begin{aligned}
= & 9.979 A-0.1495 A^{2}-2.89 \\
A & =0.0556 \theta+0.0538 \theta_{s}+0.0372 e \\
& -0.00144 \sqrt{v}(100-\theta) \\
\theta_{s} & =\theta_{d g}+0.169 \sqrt{v}\left(\theta_{d g}-\theta\right)
\end{aligned}
$$

ただし

$\theta:$ air temperature $\left({ }^{\circ} \mathrm{F}\right)$

$\theta_{s}$ : mean surrounding temperature $\left({ }^{\circ} \mathrm{F}\right)$

$e:$ pressure of aqueous vapor in the air $(\mathrm{mm}$ $\mathrm{Hg}$ )

$v:$ velocity of air stream $(\mathrm{m} / \mathrm{sec})$

$\theta_{d g}:$ temperature of the dry globe thermometer $\left({ }^{\circ} \mathbf{F}\right)$

実験により得た data を上式に代入して計算した E. W. の值を $X i$ で表わし, その場合の $\theta_{w g}$ の $Y i$ で記 
号して相関表をつくり相関く係を計算すると，

標本相関係数 $\quad r=0.837$

標本相関比 $\quad\left\{\begin{array}{l}\eta_{\mathrm{X}}=0.906 \\ \eta_{Y}=0.873\end{array}\right.$

となつた。とれらの值を検定すると， $t$-分布により有意 水淮を 0.05 にるると集団相関係数 $\rho=0$ の仮設は搭て られて $\boldsymbol{r}$ の有意性は確かである。信頼限界は信頼度を 0.9 にとる

$$
0.837+0.078>\rho>0.837-0.079
$$

となる。また相関比をみると $F$-分布により有意水準を 0.05にとると $\eta_{X}, \eta_{Y}$ ともに有意性は確かである。

以上から $\theta_{w g}$ の值は Equivalent Warmth と極めて 密接な相関々係があることが判明した。ょつて湿黒球寒 䐘計は 温度条件の 4 因子（気温，気湿，気流及び輻射 熱) の総合表示器として我々の温度感覚の面からみても 矛盾のない状態を示すむのであると結論される。

\section{考察}

1) 第 1 章に算出した実験式の他に次の式が仮定でき る。熱収支状態から風速の微小な静穏な空気の下では,

$$
\begin{aligned}
& \frac{D}{x} \cdot \frac{e_{m g}-e}{H} \sigma \rho L F t=a_{c}\left(\theta-\theta_{w g}\right) F t \\
& +p \mathcal{E}\left\{\left(\frac{T_{s}}{100}\right)^{4}-\left(\frac{T_{w g}}{100}\right)^{4}\right\} F t \cdots \cdots \cdots \cdots(9)
\end{aligned}
$$

ただし

$D$ : diffusivity of aqueous vapor in the air

$x$ : imagined thickness of air layer in heat transfer

$e_{m g}$ : maximum pressure of aqueous vapor at the temperature of the wet globe thermometer $\theta_{w g}$

$e$ : pressure of aqueous vapor in the air

$H$ : whole pressure of the air

$\sigma$ : specific gravity of aqueous vapor compared with air

$\rho$ : density of air

$L$ : latent heat of water

$F$ : area of the wet globe

$t$ : time elapse

$a_{c}$ : coefficient of heat transfer by convection

$\theta$ : air temperature

$\theta_{w g}:$ temperature of the wet globe

$p$ : emissivity of the wet globe surface

$\mathcal{E}$ : Stefan-Bolzmann constant

$T_{s}$ : mean surrounding temperature, deg. abs.
" $T_{w g}$ : temperature of the wet globe, deg. abs.

我々はとの式て $e, H, \theta_{w g}, \theta, e_{m g}, \rho, L, \sigma, \mathcal{E}, D$ の 值は実験及び常数表方ら容易に求められ，また $T_{s}$ は dry globe thermometer 办ら風速 $v$ の値を知れば容易 に間接測定できる。結局 $x, a_{c}, p$ が未知数である。 $p$ はこの計器の常数であるから, もし $\boldsymbol{x}$ が常数であるなら ば $a_{c}$ の值を求めることができるわけである。（ $a_{c}$ は温 度及び風速による変数で殊に風速に対する変化が大き い。）しかるに C. Maxwell は湿球の面を一種の電気容 量と考え, その容量を $C$ とした ${ }^{8)}$ 。すると表面積は $F$ なる故

$$
C=\frac{F}{4 \pi x} \text { ，また } C=r, F=4 \pi r^{2} \text { なる故 }(r: \text { radius }
$$

of the wet globe) $r=\frac{4 \pi r^{2}}{4 \pi x}$ からして $x=r$ となる。

即ち熱の授受の行われると仮想した空気層の厚さは湿球 の半径に等しいという奇妙な結論が出る。Cの考えを我 «の湿黒球に持つて来て前式の $x$ を $r$ 等しいと置く と $\mathrm{x}$ も常数となる。黒度 $p$ は, 水で温度 $0 \sim 100^{\circ} \mathrm{C} て$ 0.95〜0.963(Hottel の測定による)，また ten Boschに よれば $\left.60^{\circ} \mathrm{C} て ゙ 0.906 て ゙ あ る\right)^{9}$ 。また纎維のpは 0.778 0.806であるから wet globe のpはとの両者 の間の値をとることが予想される。そてで実験により得 た data から上式を計算してみるに, 一例を挙げると下 記の如くなる。

$v=0.025 \mathrm{~m} / \mathrm{sec}$ の時, $\theta=20.9^{\circ} \mathrm{C}, \theta_{w g}=18.1^{\circ} \mathrm{C}$, $\theta_{d g}=20.7^{\circ} \mathrm{C}, H=757 \mathrm{mmHg}$

とれから

$$
\begin{aligned}
& a_{c}\left(\theta-\theta_{i v g}\right)=2.8 a_{c} \\
& p \mathcal{E}\left\{\left(\frac{T_{s}}{100}\right)^{4}-\left(\frac{T_{w g}}{100}\right)^{4}\right\}=0.000344 p
\end{aligned}
$$

前式左辺項を計算するに

$$
D=D_{0}\left(\frac{T}{T_{0}}\right)^{m} p_{p_{0}}{ }^{101}
$$

ただし $p_{0}=1 \mathrm{~atm}$.

$T_{0}=273$ deg. abs.

$m=1.75$

$D_{0}=0.220 \mathrm{~cm}^{2} / \mathrm{sec}$

従つて $T$ を $\theta_{w g}$ と $\theta$ の中間平均温度にとつて

$D=0.249 \mathrm{~cm}^{2} / \mathrm{sec}, x \fallingdotseq 7.5 \mathrm{~cm}, \sigma=0.622$,

$\rho=0.001201 \mathrm{gr} / \mathrm{cm}^{3}, L=592 \mathrm{cal} / \mathrm{gr}$ より

$\frac{D}{x} \cdot \frac{e_{m g}-e}{H} \rho \sigma L=0.0000589$

従つて前式は,

$0.0000589=2.8 a_{c}+0.000344 p$ 
しかるに $p=0.8 \sim 0.9$ と考えられるから上式が成立 するならば $a_{c}<0$ となる。乙れは矛盾するから結局前 揭式がもし成立するならば， $x=r$ と仮定したととが誤 りであるととに気付く。同様のととが他の data 基に しても考えられ，結局我々は前式が成立するならば $x=r$ なる仮説は捨てなりればならない。思うに球の diameter が普通の乾湿球の如く小なる場合には $x=r$ の仮説が成 立するだろうが, diameter が大きくなれば $x<r$ とな るのではなかろらか。

温度による $a_{c}$ の変化は小さいとすれば, 近い温度 の静穏な風速下の data から最小二乗法により $p, x$ の值 を決定し，な㨷かな風速の違いでは $x$ の值に変化な いものとすれば， $a_{c}$ を変数と考えて上式から実験式が 定められるわけである。

即与 $\frac{a_{c} \cdot d}{\lambda}=f(G r), G r=\frac{d^{3} \rho \beta g(\Delta \theta)}{\mu}$

ただし

$\lambda:$ thermal conductivity of air

$d$ : diameter of the wet globe

$\beta$ : thermal coefficient of expansion of air

$g$ : acceleration due to gravity

$\mu$ : absolute viscosity of air

$\Delta \theta:$ difference between the temperature of the surface of the wet globe and that of ambient air

Gr: Grashofs number

そして $f$ の形を定めればよいととになる ${ }^{11}$ 。しかし僅 かの風速の違いでも $x$ が常に一定であるという仮説は 受入れがたい（ $\boldsymbol{p}$ は常に一定と考えられるが）から前式 の実験式導入は困難学感じた。しかし種々の場合に怙け る蒸発により失われる熱量, 強制対流による熱量, 輻射 による熱量の相関々係が判明するので捨てがたい魅力が あるから将来の研究に俟ちたい。

2 ）常に一定量の水を流下する方式を採用するならば (9) 式に更に

$$
V C_{p}\left(\theta_{w}-\theta_{w g}\right) w t
$$

$V:$ amount of supplying water per unit of time

$C_{p}$ : specific heat of water at constant pressure $w$ : specific gravity of water

$\theta_{w}$ : temperature of supplying water

の項を付加すればよいわけである。しかし左辺の蒸発に よる熱量にある係数を乗じなければならない。なんとな れば蒸発をその程度に怙いて妨げられるからである。

稿を終るに当り，との計器を創案された梶原教授の種 々の御指導によりこの実験がなされたととを付記すると こもに深甚の謝意を表す。

\section{文献}

1) 梶原三郎：労㗢衛生, 東洋書館 (東京): 213 217,1951

2) Davis, A.: Application of the Principle of Similitude to the Wet and Dry Bulb Hygrometer. Proc. Phys. Soc. 34: Ixxxv-IxxxvI, 1922

3）木谷要一：濕度測定法，2，共立出版社(東京)： 40, 1948 (内容の数字に愦がある)

4 ) 岡田武松 他: 気象学及地球物理学, 河出書房 (東京) : 11, 1939

5) Bedford, T.: The Globe Thermometer in Studies of Heating and Ventilation. J. Hygiene 34 ( 4 ) : 458-473, 1934

6 ）岡田武松：気象学, 岩波書店(東京) : 909, 1927

7) Bedford, T.: The Warmth Factor in Comfort at Work. Med. Res. Council Rep. : 76, 1937

8) Niven, W. D. : The Scientific Papers of J.C. Maxwell, I ed., Librairie Scient. J.Hermann (Paris), $2: 625-646,1927$

9 ) Bosch, M. ten : Die Wärmeübertragung, Julius Springer (Berlin): $103-108,1936$

10) Boynton, W. P., W. H. Brattain : Interdiffusion of Gases and Vapors, McGraw-Hill (New York), $5: 62,1929$

11) McAdams, W. H. : Heat Transmission, Mc Graw-Hill (New York and Lond.) : 239255, 1933

（受付：1956年 6 月13日）

ただし 